\title{
Effect of Mitigating Heat Stress in Dry Period of Surti Buffaloes on Erythrogram, Leukogram and Neutrophil to Lymphocyte Ratio during Subsequent Lactation
}

\author{
Sandhya S. Chaudhary* ${ }^{*}$ Virendra Kumar Singh and Tanvi D. Manat \\ Department of Veterinary Physiology and Biochemistry, Navsari Agricultural University, \\ Navsari, (Gujarat), India \\ *Corresponding author
}

\section{A B S T R A C T}

\section{Keywords}

Heat stress, Dry period, Surti buffaloes, Erythrogram, Leukogram, Neutrophil to lymphocyte ratio

\section{Article Info}

Accepted: 22 October 2020 Available Online: X10 November
Dry period in buffaloes is critical. Negative effects of heat stress during this period may be momentary as well as get accumulated and carried over to subsequent lactation. Present study was conducted to assess effect of mitigating heat stress in dry period of Surti buffaloes on erythrogram, leukogram and neutrophil to lymphocyte ratio during subsequent lactation. Twelve dry Surti buffaloes in their advanced gestation were selected and divided into control $(n=6)$ and treatment $(n=6)$. Mitigation of heat stress by shed modification was done only during dry period for treatment buffaloes. Treatment shed had fan for ventilation, roof whitewashed with microfine lime and $1 / 3^{\text {rd }}$ of open paddock covered with $75 \%$ green net. Blood sample was collected at $-8,-3,+1$ and +3 wk of parturition and analysed for erythrogram, leukogram and neutrophil to lymphocyte ratio. Heat ameliorative measures in shed were successful in providing thermal comfort by reducing temperature, relative humidity and THI of shed. At -3 wk $(\mathrm{P} \leq 0.05)$, +1 wk $(\mathrm{P} \leq 0.01)$ and +3 wk $(\mathrm{P} \leq 0.05) \mathrm{Hb}$ concentration and at -3 wk $(\mathrm{P} \leq 0.05)$ TEC and $\mathrm{MCHC}$ were lower in control buffaloes. TLC was significantly lower in control group of buffaloes at +3 wk $(\mathrm{P} \leq 0.05)$. In control group neutrophil $\%$ was significantly higher at -3 wk $(\mathrm{P} \leq 0.05)$ and +3 wk $(\mathrm{P} \leq 0.01)$ whereas simultaneously lymphocyte\% was significantly $(\mathrm{P} \leq 0.05)$ lower at the same time. Neutrophil to lymphocyte ratio at -3 wk $(\mathrm{P} \leq 0.05)$ and +3 wk $(\mathrm{P} \leq 0.01)$ was significantly higher in control group as compared to treatment. These results indicated presence of stress in control buffaloes. Providing thermal comfort improved profile of erythrogram and leukogram and optimized neutrophil to lymphocyte ratio. It was concluded that heat stress mitigation during dry period in buffaloes reduces immediate as well as carryover negative effects during subsequent lactation

\section{Introduction}

Dry period is a critical phase in lactating bovines. After completing the previous lactation the body becomes depleted of reserves. For optimum production there should be minimum number of open days in bovines. So normally during dry phase dairy bovines are also in advanced gestation stage. During this period there is involution of udder followed by rapid proliferation of mammary gland tissues as a preparatory measure for 
next lactation. High metabolic demands for fetal growth further strain the already exhausted state of the body. Unfortunately this being non-lactating stage of the animal is skipped of requisite attention for proper care and management. Thus it becomes very important to minimize stress at this time. However in tropical climates like that of India generally the dairy animals may encounter heat stress during dry period. Heat stress is mainly caused by intense solar radiation especially during day time. Effect of heat stress is most commonly observed as changes in erythrogram and leukogram profiles. These profiles reflect the general health, welfare and immune status of animals. They are readily and easily affected by heat stress. Neutrophil: lymphocyte (N/L) ratio an inflammatory index is commonly used to evaluate stress.

The detrimental effect of heat stress during dry period may not only be seen immediately but can also accumulate and show delayed negative impact during postpartum period as well as early lactation. Milk yield during subsequent lactation may be affected (Tao et al., 2012; Fabris et al., 2020) causing financial loss.

Buffaloes have dark skin so they absorb more radiation (Marai and Haeeb, 2010). They have limited capability to lose heat by evaporative means i.e. sweating as they have fewer sweat glands (Marai and Haeeb, 2010) that are sparsely distributed. Evaporative heat loss is the only mode that buffaloes can use at high air temperature. However in coastal regions of South Gujarat that has high relative humidity even evaporative heat loss is minimal. Thus it is essential to curtail the solar radiation by providing shade and enhance the evaporative heat loss by providing ventilation. These can be attained by modifying the shed of animals. However our understanding of heat stresses is limited to immediate effects of ameliorative measures and there is a dearth of studies that have been focussed on observing the delayed and carryover effects of heat stress. Considering that heat stress during dry period may have immediate as well as delayed negative effects during subsequent lactation the present study was planned with the objective to assess effect of mitigating heat stress in dry period of Surti buffaloes on erythrogram and leukogram profile during subsequent lactation.

\section{Materials and Methods}

The present study was approved by Institutional Animal Ethics Committee (IAEC) vide letter no. NAU/NVC/IAEC/13/2019 Dt 01/06/2019. Twelve non-lactating Surti buffaloes that were in advanced stage of gestation were randomly selected and divided into two groups i.e. Control and Treatment having six buffaloes each. Grouping was done after nullifying the parity, body weight, body condition and performance of previous lactation. Both the groups were housed in different sheds during their dry period from -8 week to calving. Shed of the control group was not modified. In the shed used for housing treatment buffaloes walls were mounted with fans, outer surface of roof was painted white with microfine lime powder and $1 / 3^{\text {rd }}$ of open paddock was covered with $75 \%$ green net. Ambient temperature and relative humidity of control and treatment shed was recorded using automated datalogging device (HTC make) during the dry period. Temperature humidity index (THI) was calculated using the formula given by (Tucker et al., 2008).

Blood samples were collected at $-8,-3,+1$ and +3 weeks of calving from all the animals. Whole blood was collected in vacutainer containing $\mathrm{K}_{3}$ EDTA. Blood was analyzed immediately after collection using fully automated haematology cell counter 
(MEDONIC CA 620/530 VET) for haemoglobin $(\mathrm{Hb})$, packed cell volume (PCV) and total erythrocyte count (TEC) and total leucocyte count (TLC). Hematological indices mean corpuscular volume (MCV), mean corpuscular hemoglobin $(\mathrm{MCH})$ and mean corpuscular haemoglobin concentration (MCHC) were derived using suitable formulae. Differential leucocyte count was performed. Neutrophil: Lymphocyte (N/L) ratio was calculated. The data was subjected to analysis of variance (Snedecor and Cochran, 1980) and the means were tested for significance by Duncan's multiple range test at $5 \%$ and $1 \%$. Results were presented as Mean \pm SE.

\section{Results and Discussion}

Results for meteorological parameters of both sheds during dry period are presented in table 1. Results for erythrogram and leukogram profile are presented in table 2 and 3 respectively. Neutrophil: lymphocyte (N/L) ratios are presented in fig. 1 .

\section{Meteorological parameters}

During complete dry period ambient temperature, relative humidity and THI range for average daily values, average values only during daytime and only during night were lower for treatment shed. Whitewashing with microfine lime powder minimized the absorption of incident solar radiation on roof. Green net was successful in restricting the incident solar radiation on floor of open paddock. Fans mounted on wall increased the movement of air in shaded area thereby reducing relative humidity, increasing convective heat loss and producing cooling effect. The effects were more prominent during daytime than night. Even though the range of ambient temperature and THI was only slightly higher in control shed but it indicates that the beneficial effects of heat amelioration during day is evident also during night.

\section{Erythrogram profile}

Between groups haemoglobin concentration was significantly lower in buffaloes of control shed at -3 wk $(\mathrm{P} \leq 0.05),+1 \mathrm{wk}(\mathrm{P} \leq 0.01)$ and +3 wk $(\mathrm{P} \leq 0.05)$. Total erythrocyte count and MCHC were significantly lower at -3 wk $(\mathrm{P} \leq 0.05)$. During heat stress paucity of nutrients or reduced feed intake may decrease $\mathrm{Hb}$ synthesis and increased free radical injury may lyse erythrocytes to reduce their concentrations in blood (Srikandakumar and Johnson, 2004). Similar to the findings of the present study a lowered $\mathrm{Hb}$ concentration and reduced TEC were observed in heat stressed cattle (Berian et al., 2019).

\section{Leukogram profile}

TLC did not differ significantly during preapartum but was significantly lower in control group of buffaloes at +3 wk. Heat stress decreases concentration of leucocytes (Bhan et al., 2012) but in contrast higher TLC due to heat stress (Omron et al, 2013; Mazullo et al., 2014 and Morar et al 2018) have also been reported. It has also been found that heat stress causes release of stress hormones that increases the leukocyte concentration in circulation (Seixas et al., 2014). However these studies focussed more on immediate or concomitant levels rather than investigating the delayed effects. The time lag for decreased TLC of control buffaloes in present study could be a delayed response to chronic heat stress that needs further investigation in future studies.

DLC results revealed that in control buffaloes neutrophils\% were significantly higher at -3 wk $(\mathrm{P} \leq 0.05)$ and +3 wk $(\mathrm{P} \leq 0.01)$ whereas simultaneously lymphocyte $\%$ were significantly $(\mathrm{P} \leq 0.05)$ lower at the same time. 
Table 1 : Range of ambient temperature, relative humidity and THI of shed during dry period

\begin{tabular}{|c|c|c|c|c|c|c|}
\hline & \multicolumn{2}{|c|}{ Daily avg } & \multicolumn{2}{|c|}{ Day avg } & \multicolumn{2}{|c|}{ Night avg } \\
\hline & Control & Treatment & Control & Treatment & Control & Treatment \\
\hline $\begin{array}{l}\text { Amb } \\
\text { Temp } \\
\left({ }^{\circ} \mathrm{C}\right)\end{array}$ & $31.11-32.19$ & $29.19-29.28$ & $36.20-37.32$ & $32.49-32.97$ & $26.02-27.05$ & $25.57-25.97$ \\
\hline RH (\%) & $72.09-78.76$ & $67.81-75.62$ & $61.32-68.48$ & $54.32-63.30$ & $82.86-89.04$ & $81.29-87.94$ \\
\hline THI & $83.43-85.78$ & $79.85-81.21$ & $88.88-91.47$ & $82.39-84.75$ & $76.89-79.10$ & $76.05-76.79$ \\
\hline
\end{tabular}

\begin{tabular}{|c|c|c|c|c|c|c|c|c|}
\hline & \multicolumn{2}{|c|}{$-8 w k$} & \multicolumn{2}{|c|}{$-3 \mathrm{wk}$} & \multicolumn{2}{|c|}{$+1 \mathrm{wk}$} & \multicolumn{2}{|c|}{$+3 \mathrm{wk}$} \\
\hline & Control & Treatment & Control & Treatment & Control & Treatment & Control & Treatment \\
\hline $\begin{array}{c}\text { Hb } \\
\text { (g/dl) }\end{array}$ & $\begin{array}{l}10.02 \\
\pm 0.22\end{array}$ & $\begin{array}{l}10.12 \\
\pm 0.14\end{array}$ & $\begin{array}{l}9.22 * \\
\pm 0.25\end{array}$ & $\begin{array}{l}9.91 * \\
\pm 0.12\end{array}$ & $\begin{array}{l}7.64 * * \\
\pm 0.26\end{array}$ & $\begin{array}{l}9.31 * * \\
\pm 0.17\end{array}$ & $\begin{array}{l}9.39 * \\
\pm 0.20\end{array}$ & $\begin{array}{l}9.99 * \\
\pm 0.13\end{array}$ \\
\hline $\begin{array}{l}\text { PCV } \\
(\%)\end{array}$ & $\begin{array}{l}37.25 \\
\pm 0.61\end{array}$ & $\begin{array}{l}37.57 \\
\pm 0.94\end{array}$ & $\begin{array}{l}36.53 \\
\pm 0.62\end{array}$ & $\begin{array}{l}37.26 \\
\pm 0.97\end{array}$ & $\begin{array}{l}35.04 \\
\pm 0.56\end{array}$ & $\begin{array}{l}36.96 \\
\pm 0.89\end{array}$ & $\begin{array}{l}36.69 \\
\pm 0.63\end{array}$ & $\begin{array}{l}37.42 \\
\pm 0.96\end{array}$ \\
\hline $\begin{array}{c}\text { TEC } \\
\left(10^{6} / \mathrm{mm}^{3}\right)\end{array}$ & $\begin{array}{c}5.67 \\
\pm 0.08\end{array}$ & $\begin{array}{c}5.62 \\
\pm 0.13\end{array}$ & $\begin{array}{l}4.95^{*} \\
\pm 0.12\end{array}$ & $\begin{array}{l}5.37 * \\
\pm 0.12\end{array}$ & $\begin{array}{c}4.71 \\
\pm 0.14\end{array}$ & $\begin{array}{c}5.03 \\
\pm 0.15\end{array}$ & $\begin{array}{c}5.07 \\
\pm 0.11\end{array}$ & $\begin{array}{c}5.36 \\
\pm 0.16\end{array}$ \\
\hline $\begin{array}{c}\text { MCV } \\
\text { (fl) }\end{array}$ & $\begin{array}{l}65.70 \\
\pm 0.94\end{array}$ & $\begin{array}{l}67.15 \\
\pm 2.61\end{array}$ & $\begin{array}{l}74.03 \\
\pm 1.65\end{array}$ & $\begin{array}{l}69.63 \\
\pm 2.57\end{array}$ & $\begin{array}{l}74.62 \\
\pm 1.79\end{array}$ & $\begin{array}{l}73.78 \\
\pm 2.20\end{array}$ & $\begin{array}{l}72.54 \\
\pm 1.71\end{array}$ & $\begin{array}{l}70.13 \\
\pm 2.85\end{array}$ \\
\hline MCH (pg) & $\begin{array}{l}17.70 \\
\pm 0.62\end{array}$ & $\begin{array}{r}18.07 \\
\pm 0.48\end{array}$ & $\begin{array}{l}18.75 \\
\pm 0.94\end{array}$ & $\begin{array}{l}18.53 \\
\pm 0.56\end{array}$ & $\begin{array}{l}16.37 \\
\pm 1.05\end{array}$ & $\begin{array}{l}18.58 \\
\pm 0.46\end{array}$ & $\begin{array}{l}18.61 \\
\pm 0.77\end{array}$ & $\begin{array}{l}18.70 \\
\pm 0.56\end{array}$ \\
\hline $\begin{array}{c}\text { MCHC } \\
\text { (g/dl) }\end{array}$ & $\begin{array}{l}26.95 \\
\pm 0.88\end{array}$ & $\begin{array}{l}27.03 \\
\pm 0.78\end{array}$ & $\begin{array}{c}25.29 * \\
\pm 0.91\end{array}$ & $\begin{array}{c}26.69^{*} \\
\pm 0.73\end{array}$ & $\begin{array}{l}21.86 \\
\pm 0.99\end{array}$ & $\begin{array}{l}25.23 \\
\pm 0.42\end{array}$ & $\begin{array}{l}25.65 \\
\pm 0.81\end{array}$ & $\begin{array}{l}26.76 \\
\pm 0.65\end{array}$ \\
\hline
\end{tabular}

\begin{tabular}{|c|c|c|c|c|c|c|c|c|}
\hline & \multicolumn{2}{|c|}{$-8 w k$} & \multicolumn{2}{|c|}{ - 3 wk } & \multicolumn{2}{|c|}{$+1 \mathrm{wk}$} & \multicolumn{2}{|c|}{$+3 \mathrm{wk}$} \\
\hline & Control & Treatment & Control & Treatment & Control & Treatment & Control & Treatment \\
\hline $\begin{array}{c}\text { TLC } \\
\left(10^{3} / \mathbf{m m}^{3}\right)\end{array}$ & $\begin{array}{c}6.04 \\
\pm 0.11\end{array}$ & $\begin{array}{c}6.16 \\
\pm 0.12\end{array}$ & $\begin{array}{c}6.04 \\
\pm 0.11\end{array}$ & $\begin{array}{c}6.16 \\
\pm 0.12\end{array}$ & $\begin{array}{c}7.40 \\
\pm 0.15\end{array}$ & $\begin{array}{r}7.26 \\
\pm 0.28\end{array}$ & $\begin{array}{l}6.99 * \\
\pm 0.27\end{array}$ & $\begin{array}{l}7.98^{*} \\
\pm 0.20\end{array}$ \\
\hline $\begin{array}{c}\text { Neutrophils } \\
(\%)\end{array}$ & $\begin{array}{l}42.83 \\
\pm 0.79\end{array}$ & $\begin{array}{l}42.67 \\
\pm 0.56\end{array}$ & $\begin{array}{c}49.33^{*} \\
\pm 0.92\end{array}$ & $\begin{array}{l}45.50 * \\
\pm 1.31\end{array}$ & $\begin{array}{l}50.67 \\
\pm 1.50\end{array}$ & $\begin{array}{l}52.17 \\
\pm 1.35\end{array}$ & $\begin{array}{c}56.67 * * \\
\pm 1.12\end{array}$ & $\begin{array}{c}48.83 * * \\
\pm 2.15\end{array}$ \\
\hline $\begin{array}{c}\text { Eosinophils } \\
(\%)\end{array}$ & $\begin{array}{c}5.17 \\
\pm 0.31\end{array}$ & $\begin{array}{c}5.00 \\
\pm 0.37\end{array}$ & $\begin{array}{c}4.50 \\
\pm 0.50\end{array}$ & $\begin{array}{c}4.33 \\
\pm 0.56\end{array}$ & $\begin{array}{c}3.50 \\
\pm 0.43\end{array}$ & $\begin{array}{c}3.00 \\
\pm 0.37\end{array}$ & $\begin{array}{c}3.17 \\
\pm 0.31\end{array}$ & $\begin{array}{c}3.33 \\
\pm 0.33\end{array}$ \\
\hline $\begin{array}{c}\text { Basophils } \\
(\%)\end{array}$ & $\begin{array}{c}2.00 \\
\pm 0.37\end{array}$ & $\begin{array}{c}1.83 \\
\pm 0.31\end{array}$ & $\begin{array}{c}1.50 \\
\pm 0.22\end{array}$ & $\begin{array}{c}1.17 \\
\pm 0.17\end{array}$ & $\begin{array}{c}1.33 \\
\pm 0.21\end{array}$ & $\begin{array}{c}1.50 \\
\pm 0.22\end{array}$ & $\begin{array}{c}1.33 \\
\pm 0.21\end{array}$ & $\begin{array}{c}1.50 \\
\pm 0.22\end{array}$ \\
\hline $\begin{array}{c}\text { Lymphocytes } \\
(\%)\end{array}$ & $\begin{array}{l}46.17 \\
\pm 0.60\end{array}$ & $\begin{array}{l}45.83 \\
\pm 0.60\end{array}$ & $\begin{array}{c}42.00^{*} \\
\pm 0.89\end{array}$ & $\begin{array}{l}45.17 * \\
\pm 0.98\end{array}$ & $\begin{array}{l}42.83 \\
\pm 1.28\end{array}$ & $\begin{array}{l}41.33 \\
\pm 1.20\end{array}$ & $\begin{array}{c}36.17 * \\
\pm 1.25\end{array}$ & $\begin{array}{l}44.17 * \\
\pm 2.47\end{array}$ \\
\hline $\begin{array}{c}\text { Monocytes } \\
(\%)\end{array}$ & $\begin{array}{c}3.83 \\
\pm 0.17\end{array}$ & $\begin{array}{c}4.67 \\
\pm 0.49\end{array}$ & $\begin{array}{c}2.67 \\
\pm 0.56\end{array}$ & $\begin{array}{c}3.83 \\
\pm 0.48\end{array}$ & $\begin{array}{c}1.67 \\
\pm 0.33\end{array}$ & $\begin{array}{c}2.00 \\
\pm 0.45\end{array}$ & $\begin{array}{c}2.67 \\
\pm 0.67\end{array}$ & $\begin{array}{c}2.17 \\
\pm 0.48\end{array}$ \\
\hline
\end{tabular}




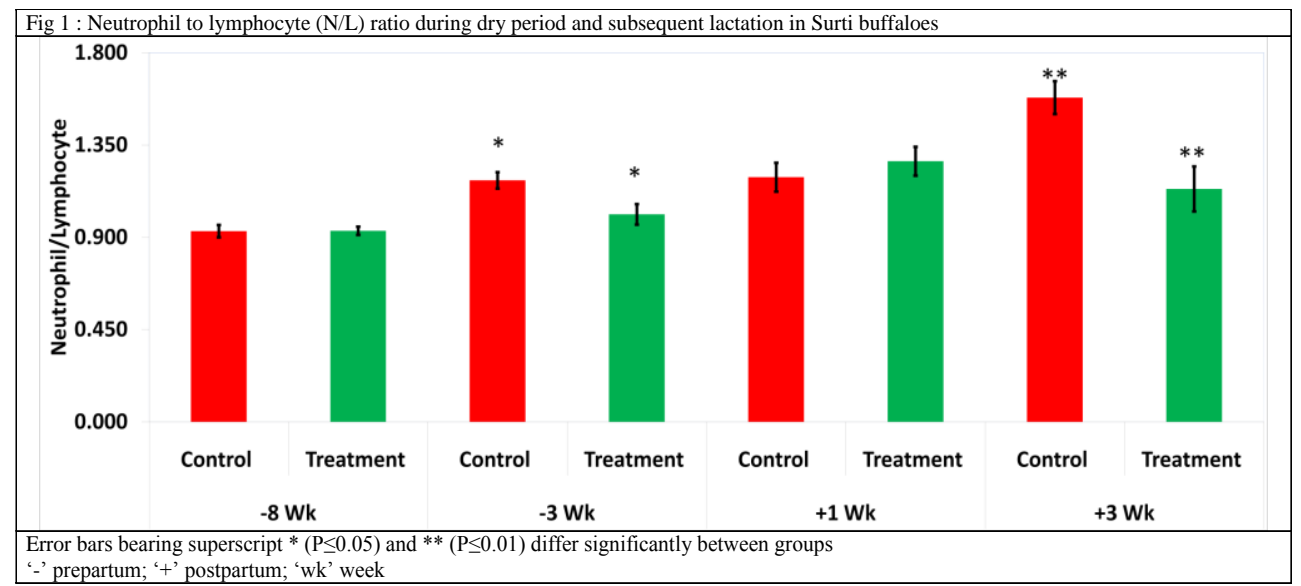

During stress, increased glucocorticoid secretion may mobilize sequestered neutrophils from bone marrow and increase them in circulation (Jain, 1993). Lymphocytes have been reported to decrease in response to heat stress (Van Eerd, 2019; Devaraj and Upadhyay, 2007). Heat stress especially during late gestation has been demonstrated in vitro and ex vivo to decrease $\mathrm{CD} 4+\mathrm{T}$ lymphocytes (Gomes et al., 2013). Lymphocytes under thermal stress also show lower proliferation in vitro (Lacetera et al., 2005; Lacetera et al., 2006; Kamanga-Sollo et al., 2011). Similar to the findings of the present study an increase in neutrophil concentration has been attributed to heat stress or summer season (Naik et al., 2013; Koubková et al., 2002; Mayengbam, 2009).

\section{Neutrophil: Lymphocyte (N/L) ratio}

Neutrophil: Lymphocyte (N/L) ratio in control and treatment buffaloes at $-8,-3,+1$ and +3 weeks were $0.930 \pm 0.03,0.932 \pm 0.02$; $1.178 \pm 0.04,1.012 \pm 0.05 ; 1.193 \pm 0.07$, $1.271 \pm 0.07$ and $1.581 \pm 0.08,1.136 \pm 0.11$ respectively. Neutrophil: lymphocyte (N/L) ratio at -3 wk $(\mathrm{P} \leq 0.05)$ and +3 wk $(\mathrm{P} \leq 0.01)$ were significantly higher in control group as compared to treatment. N/L ratio was lowest at the beginning of dry period i.e. at $-8 \mathrm{wk}$ in both the groups and increased thereafter. The ratio of neutrophil: lymphocyte in blood is considered as inflammatory index and often calculated to evaluate stress. It acts as a good indicator of thermal stress (Stanger et al., 2005). In the present study significantly higher N/L ratio in control buffaloes at $-3 \mathrm{wk}$ $(\mathrm{P} \leq 0.05) \quad$ was observed and it was predominantly due to heat stress. The margin of increase in $\mathrm{N} / \mathrm{L}$ ratio was further more at $+3 \mathrm{wk}(\mathrm{P} \leq 0.01)$ and it was highly significant. This was attributed to cumulative impact of accumulated and delayed deleterious effects of heat stress of dry period along with stress that is frequently observed during early lactation when it is approaching peak yield.

As also mentioned before cortisol plays a dual role in regulating N/L ratio. Higher cortisol level during stress enhances mobilization of sequestered neutrophils and increases their concentration in circulation as was seen in the present study in control group. Such increase during summer months has been reported by Naik et al., (2013). However increased cortisol levels not only decreases lymphocytes in circulation as seen in the control group of buffaloes in the present study but also diminish its potential to proliferate. Stress due to heat during summers has been reported to reduce lymphocyte concentration in Murrah buffaloes (Dayal, 2017). Simultaneous decrease in lymphocytes and increase in neutrophils, leading to an increase in the neutrophil: lymphocyte ratio occurs under 
stressful conditions (Dhabhar et al., 1996). Glucocorticoids released during stress enhance the life span of neutrophils thus increasing their concentration whereas higher glucocorticoids also cause lymphopenia simultaneously (Butcher and Lord, 2004; Claman, 1972; Zhang et al., 2001). An early study done by Stull and McMartin (1992) had indicated that neutrophils to lymphocytes $(\mathrm{N}$ : L) ratio is high due to heat exposure. Parmar et al (2013) in their study revealed that increase in neutrophil to lymphocyte ratio was significant in Murrah buffaloes but not significant in Sahiwal cows indicating that buffaloes are more prone to heat stress.

In conclusion the modification of shed for dairy buffalo by covering open paddock with green net, whitewashing of roof with microfine lime powder and using of wall mounted fans provides thermal comfort. Thermal comfort improves erythrogram as well as leukogram picture and optimizes neutrophil to lymphocyte ratio. Heat stress mitigation during dry period of buffaloes is important to reduce immediate as well as carryover negative effects during subsequent lactation.

\section{Acknowledgement}

Authors are thankful to Dean, Veterinary College, NAU for financial support and Research Scientist, Livestock Research Station, NAU along with concerned staff for providing animals and facilitating the study at farm.

\section{References}

Berian, S., Gupta, S. K., Sharma, S., Ganai, I., Dua, S., and Sharma, N. 2019. Effect of Heat Stress on Physiological and Hemato-biochemical Profile of Cross Bred Dairy Cattle. Journal of Animal Research, 9(1):95-101.
Bhan, C., Singh, S. V., Hooda, O. K., Upadhyay, R. C., Beenam, V. M., and Mangesh, V. 2012. Influence of temperature variability on physiological, hematological and biochemical profile of growing and adult sahiwal cattle. Journal of Environmental Research and Development, 7(2A): 986-994.

Butcher, S.K. and Lord, J.M. 2004. Stress responses and innate immunity: aging as a contributory factor. Aging Cell 3:151-160

Claman, H. N. 1972. Corticosteroids and lymphoid cells. New England Journal of Medicine, 287: 388-397

Dayal, S., Dey, A., Pandian, S. J., Gupta, J. J., Chandran, P. C. and Ali, I. 2017. Effect of seasonal variation on physiological parameters in Murrah buffaloes. Indian Journal of Animal Sciences, 87(8): 965-967

Devaraj, C., and Upadhyay, R. C. 2007. Effect of catecholamines and thermal exposure on lymphocyte proliferation, IL $-1 \alpha \& \beta$ in buffaloes. Italian Journal of Animal Science, 6(2): 1336-1339.

Dhabhar, F. S., Miller, A. H., McEwen, B. S., and Spencer, R. L. 1996. Stressinduced changes in blood leukocyte distribution. Role of adrenal steroid hormones. The journal of immunology, 157(4): 1638-1644.

Fabris, T. F., Laporta, J., Skibiel, A. L., DadoSenn, B., Wohlgemuth, S. E., and Dahl, G. E. 2020. Effect of heat stress during the early and late dry period on mammary gland development of Holstein dairy cattle. Journal of Dairy Science, 103(9): 8576-8586.

Gomes, C.G., Zuniga, J.E., Karakaya, E., Greco, L.F., Sinedino, L.D.P., Martinez, N., Bisinotto, R.S., Ribeiro, E.S., Junior, P.L., Engstrom, M.A., and Driver, J.P., 2013. Effects of prepartum evaporative cooling and 
vitamin E supplementation on immune function of Holstein cows during summer in Florida. Journal of Dairy Science, 97(1): 725.

Jain, N. C. 1993. Essential of veterinary hematology. copyrights by Lea and Febiger Philadelphia.

Kamanga-Sollo, E., Pampusch, M. S., White, M. E., Hathaway, M. R., and Dayton, W. R. 2011. Effects of heat stress on proliferation, protein turnover and abundance of heat shock protein messenger ribonucleic acid in cultured porcine muscle satellite cells. Journal of animal science, 89(11): 3473-3480.

Koubkova, M., Knizkova, L., Kunc, P., Hartlova, H., Flusser, J., and Dolezal, O. 2002. Influence of high environmental temperatures and evaporative cooling on some physiological, hematological and biochemical parameters in highyielding dairy cows. Czech Journal of Animal Science, 47(8): 309-318.

Lacetera, N., Bernabucci, U., Scalia, D., Basiricò, L., Morera, P., and Nardone, A. 2006. Heat stress elicits different responses in peripheral blood mononuclear cells from Brown Swiss and Holstein cows. Journal of Dairy Science, 89(12): 4606-4612.

Lacetera, N., Bernabucci, U., Scalia, D., Ronchi, B., Kuzminsky, G., and Nardone, A. 2005. Lymphocyte functions in dairy cows in hot environment. International Journal of Biometeorology, 50(2):105-110.

Marai, I. F. M. and Haeeb, A. A. M., 2010. Buffalo's biological functions as affected by heat stress-A review. Livestock Science, 127(2-3): 89-109.

Mayengbam, P. 2009. Heat shock protein 72 expression in relation to thermotolerance sahiwal and holsteinfriesian crossbred cattle. Doctoral dissertation, NDRI, Karnal.

Mazzullo, G., Rifici, C., Caccamo, G., Rizzo, M., and Piccione, G. 2014. Effect of different environmental conditions on some haematological parameters in cow. Annals of Animal Science, 14(4): 947-954.

Morar, D., Ciulan, V., Simiz, F., Moț, T., Hutu, I., and Văduva, C. 2018. Effect of heat stress on haematological parameters in dairy cows. Lucrari Stiintifice-Universitatea de Stiinte Agricole a Banatului Timisoara, Medicina Veterinara, 51(2): 65-70.

Naik, B. R., Kumar, A. V. N. S., Ravi, A., Bramhaiah, K. V., and Chakravarthi, V. P. 2013. Effect of seasons on physiological and hematological values in Punganur cattle. International Journal of Pharma and Bio Sciences, 4(4).

Omran, F. I., Shafie, M. M., Ashour, G. H., Youssef, M. M., and Hassan, L. R. 2013. Response of buffalo calves exposed to first and second acute thermal shocks. Egyptian Journal of Agricultural Research, 91: 1113-1127.

Parmar, M. S., Madan, A. K., Rastogi, S. K., and Huozha, R. 2013. Comparative Study of Seasonal Variations on Hematological Profile in Sahiwal Cows (Bos Indicus) and Murrah Buffalo (Bubalus Bubalis). Journal of Animal Research, 3(2): 167-171.

Seixas, L., de Melo, C. B., Tanure, C. B., Peripolli, V., and McManus, C. 2017. Heat tolerance in Brazilian hair sheep. Asian-Australasian Journal of Animal Sciences, 30(4): 593.

Snedecor, G.W., and Cochran, W.G. 1980 Statistical Methods. $7^{\text {th }}$ ed. Iowa State University Press, Ames, Iowa,USA. p593.

Srikandakumar, A. and Johnson, E. H. 2004. Effect of heat stress on milk production, rectal temperature, 
respiratory rate and blood chemistry in Holstein, Jersey and Australian Milking Zebu cows. Tropical Animal Health and Production, 36(7): 685-692

Stanger, K. J., Ketheesan, N., Parker, A. J., Coleman, C. J., Lazzaroni, S. M., and Fitzpatrick, L. A. 2005. The effect of transportation on the immune status of Bos indicus steers. Journal of Animal Science, 83(11): 2632-2636.

Stull, C.L. and McMartin, D.A. 1992. Welfare Parameters in Veal Calf Productions Facilities. Coop. Extn.. University of California, Davis.

Tao, S., Monteiro, A. P. A., Thompson, I. M., Hayen, M. J., and Dahl, G. E. 2012. Effect of late-gestation maternal heat stress on growth and immune function of dairy calves. Journal of dairy science, 95(12): 7128-7136.
Tucker, C. B., Rogers, A. R., and Schütz, K. E. 2008. Effect of solar radiation on dairy cattle behaviour, use of shade and body temperature in a pasturebased system. Applied Animal Behaviour Science, 109(2-4): 141154.

Van Eerd, N. M. 2019. Evaluating heat stress response in lactating holstein cows with supplementation of a feed additive during mid lactation. Thesis, The University of Arizona.

Zhang, X.H., Moilanen, E. and Kankaanranta, H. 2001. Beclomethasone, budessonide and fluticasone propionate inhibit human neutrophil apoptosis. European Journal of Pharmacology. 431:365-371

\section{How to cite this article:}

Sandhya S. Chaudhary, Virendra Kumar Singh and Tanvi D. Manat. 2020. Effect of Mitigating Heat Stress in Dry Period of Surti Buffaloes on Erythrogram, Leukogram and Neutrophil to Lymphocyte Ratio during Subsequent Lactation. Int.J.Curr.Microbiol.App.Sci. 9(11): 32443251. doi: https://doi.org/10.20546/ijcmas.2020.911.389 